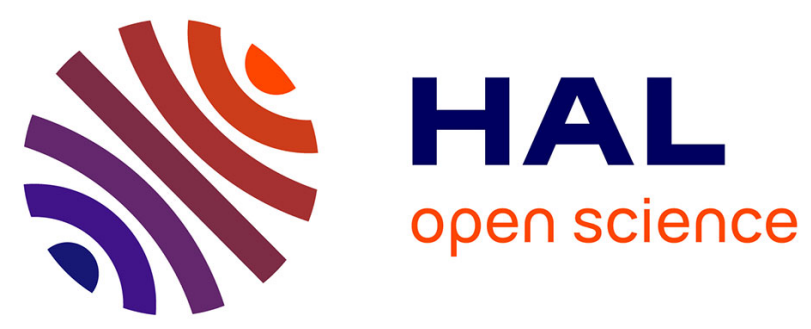

\title{
Perceptions of Teachers and Guardians on the Electronic Record in the School-Family Communication
}

\author{
António Abreu, Álvaro Rocha, Manuel Pérez Cota
}

\section{To cite this version:}

António Abreu, Álvaro Rocha, Manuel Pérez Cota. Perceptions of Teachers and Guardians on the Electronic Record in the School-Family Communication. 14th Conference on e-Business, e-Services and e-Society (I3E), Oct 2015, Delft, Netherlands. pp.48-62, 10.1007/978-3-319-25013-7_5 . hal01448069

\section{HAL Id: hal-01448069 \\ https://hal.inria.fr/hal-01448069}

Submitted on 27 Jan 2017

HAL is a multi-disciplinary open access archive for the deposit and dissemination of scientific research documents, whether they are published or not. The documents may come from teaching and research institutions in France or abroad, or from public or private research centers.
L'archive ouverte pluridisciplinaire HAL, est destinée au dépôt et à la diffusion de documents scientifiques de niveau recherche, publiés ou non, émanant des établissements d'enseignement et de recherche français ou étrangers, des laboratoires publics ou privés. 


\title{
Perceptions of Teachers and Guardians on the Electronic Record in the School-Family Communication
}

\author{
António Abreu ${ }^{1}$, Álvaro Rocha ${ }^{2}$, Manuel Pérez Cota $^{3}$ \\ ${ }^{1}$ ISCAP-IPP, Rua Jaime Lopes Amorim, s/n, 4465-004 S. Mamede de Infesta, Portugal \\ ${ }^{2}$ DEI, University of Coimbra, Pólo II - Pinhal de Marrocos, 3030-290 Coimbra, Portugal \\ ${ }^{3}$ EEI, University of Vigo, Campus Torrecedeira, Rúa Torrecedeira, 86, 36280 Vigo, Spain \\ aabreu@iscap.ipp.pt, amrocha@dei.uc.pt, mpcota@uvigo.es
}

\begin{abstract}
This paper presents the first stage of an investigation work whose purpose is to introduce a new form of communication between the school and the family, through an electronic record (ER). We tried to identify, with a questionnaire, the perceptions of Teachers and Guardians towards the adoption of an ER. Both groups underlined the importance of communication between the school and the family, and expressed interest in the ER, as a communicational tool.
\end{abstract}

Keywords: School; Family; School-Family Relationship; Communication; Electronic Record.

\section{Introduction}

The present study, focused on the communication, management and dissemination of information in digital environments, is of great significance and interest. We intent to give our contribution to the communication between the school and the family, with the development of an Electronic Record (ER).

Indeed, the technological revolution imposed changes both in society $[1,12,14$, $19,20,32]$ and in the forms of communication, which exceed barriers of space and time $[6,7,25]$.

Schools should use electronic resources to develop new forms of communication between the school and the family $[3,4,20,26,27,28,32]$, hence de ER $[14,15,16$, 17, 21, 33].

Currently, this communication is established via the traditional student record (TR), in paper format, which is not the most direct contact vehicle, as it requires the mediation of the student and, moreover, limits the communication content [21].

In order to render this communication easier [20], the need make the TR a more dynamic and attractive tool, both to families and the school, emerged, and this may be achieved with the ER.

We intend to develop a study that assumes as a starting point three investigation questions: 
- Is the school-family communication fundamental for the teaching-learning process?

- Is the TR a fundamental tool for school-family communication?

- Does the ER improve and increase the potential of school-family communication?

This study comprised three stages. The first stage, the focus of this paper, involved a feasibility study as to the adoption of the ER in school-family relationships, based on the perceptions of Guardians and Teachers.

\section{Investigation Methodology}

In this stage of the study, we adopted the survey investigation method, to the extent that this constitutes a viable and desirable method within a school environment and generates accurate and reliable measures which allow for a statistical analysis [6]. The adopted tool was the questionnaire, divided in two parts: the first focused on the characterization of the sample and the latter being the questionnaire itself, which, in its turn, included Part B, pertaining to the "Student Record", and Part C, concerning the "Inclusion of items in an Electronic Report". We adopted a Likert type ordinal scale with five answer alternatives (from " 1 " to " 5 ") that ranged from "Completely disagree" to "Completely agree".

For this investigation work we developed the following hypothesis:

H1: The educational community values communication between the school and the family;

H2: The TR is a fundamental tool in school-family communication;

H3: The ER improves school-family communication.

We conducted a pre-test in a group of thirty Teachers and Guardians, in order to clarify and validate the questionnaire. As the questionnaire did not offer doubts, we moved to the questionnaire distribution stage, in paper format and on-line, amongst the participating schools and school groupings, considering the answering availability on the part of the respondents and according to the preferences of School Principals.

The survey was carried in the form of a questionnaire in schools and cooperative/private and public schools located in the North, Centre and South of the country, between November 17, 2013 and March 8, 2014. In an informal meeting the School Principals were informed as to the purpose of the study and the entire questionnaire administration process, and they in turn, together with the responsible parties of the school groupings, had to explain Teachers, class directors, elements from parent associations and Guardians the purpose of the investigation work and how they could participate.

The obtained data was treated with the SPSS computer program, version 20. Besides the descriptive data analysis, we carried out a correlational analysis, crossing some of the variables comprised by the questionnaire, in order to find the answers to the three laid out investigation hypothesis [22]. We also used absolute (standard deviation) and relative (coefficient of variation) measures of dispersion, useful when describing the observed variation in the values of a set and informing us as to the homogeneity. The smaller $(<1)$ the standard deviation and $(<=20 \%)$ the coefficient of 
variation, the smaller the dispersion and, consequently, the more homogenous the answers.

\subsection{Characterization of the Sample}

The sample included 1002 Guardians of students attending basic and secondary education and 300 Teachers exercising their professional activity in cooperative/private and public educational institutions.

\subsection{Factor Analysis}

We carried out a data analysis to the questions comprising Part B and Part C of the Guardians and Teachers questionnaires, adopting data treatment techniques that allowed us to agglomerate the initial information, with a view to render the analysis easier [23].

We selected the principal components method, in order to isolate the original correlating variables, constituting factors [24].

The factor analysis method analyses a set of variables with the purpose of verifying the possibility of grouping answers that are similarly interpreted by the elements of the sample, in order to determine their position within the set of variables [9], [29], [30]. This allows us to turn the variables of a scale into a smaller number of factors: the principal components. To define the number of components to be retained, we carried out a preliminary analysis, applying the factor analysis and interpreting the obtained results [8].

In part B of the Teachers and Guardians questionnaires, concerning the "Student Record", we drew our factors from the 15 variables presented in table 1.

We began our analysis with the de Kaiser Meyer Olkin (KMO) and the Bartlett tests, which determine the quality of the factor analysis to the sample data [2], [10].

After analysing the test results, the $K M O$ revealed a value of 0.887 and the Bartlett a significance value below $5 \%$, the factor analysis to component B of the Guardians and Teachers questionnaires was considered feasible [12].

Using the principal components method, we proceeded with the extraction of factors from the 15 variables, adopting the Kaiser criterion (eigenvalues above one), complying with the requirement that factors should explain at least approximately $60 \%$ of the total variation observed in the original variables [10]. We retained four factors, which explain $66.7 \%$ of the total variation observed in the original 15 variables.

Through the Varimax method we were able to obtain the extreme values of the coefficients relating each variable to the retained factors, in order to associate each variable with a single factor [5]: Factor 1 - ER; Factor 2 - Impact of the schoolfamily relationship in the teaching learning process; Factor 3 - TR; Factor 4 - Schoolfamily relationship difficulties. 
Table 1. Part B of the Teachers and Guardians Questionnaires - "Student Report".

\begin{tabular}{|c|c|}
\hline \multicolumn{2}{|r|}{ Part B of the Teachers and Guardians questionnaires - "Student Record". } \\
\hline \# & Item \\
\hline 1 & The relationship between the family and the school is fundamental for the teaching-learning process. \\
\hline 2 & $\begin{array}{l}\text { The relationship between the school and the family is not always easy and stands out as a complex } \\
\text { relationship. }\end{array}$ \\
\hline 3 & Whenever the parents are involved the development of the students is potentially improved. \\
\hline 4 & $\begin{array}{l}\text { The participation of parents in the school benefits the Teachers and contributes to a more constructive } \\
\text { work on their part. }\end{array}$ \\
\hline 5 & $\begin{array}{l}\text { Parents assume more favourable attitudes towards Teachers when they cooperate constructively with } \\
\text { each other. }\end{array}$ \\
\hline 6 & $\begin{array}{l}\text { Parents can easily head to the school during the receiving hours appointed by Class Directors and in } \\
\text { meeting days. }\end{array}$ \\
\hline 7 & The Traditional Student Record constitutes an important tool in family-school communications. \\
\hline 8 & Teachers regularly use the Traditional Record in their communications with Guardians. \\
\hline 9 & $\begin{array}{l}\text { It is important to find a tool that will allow for the intensification of and an easier communication } \\
\text { between the School and the Guardian. }\end{array}$ \\
\hline 10 & $\begin{array}{l}\text { The adoption of an Electronic Report may contribute to an improved communication between the } \\
\text { school and the Guardian. }\end{array}$ \\
\hline 11 & $\begin{array}{l}\text { An Electronic Record may constitute an important work tool for Class Directors, Teachers, Parents } \\
\text { and School Principals. }\end{array}$ \\
\hline 12 & $\begin{array}{l}\text { An Electronic Report may constitute a communication resource between every Teacher and } \\
\text { Guardians. }\end{array}$ \\
\hline 13 & An Electronic Report may be used by School Principals to contact Teachers. \\
\hline 14 & An Electronic Report may be used by School Principals to contact Guardians. \\
\hline 15 & $\begin{array}{l}\text { An Electronic Record offers more advantages than the Traditional Record where the communication } \\
\text { between the multiple school community actors is concerned. }\end{array}$ \\
\hline
\end{tabular}

Table 2 presents the factorial matrix after the Varimax rotation, where the saturation between each factor and the principal components can be observed. The saturations of the variables in each factor are always higher than the required minimum of $40 \%$. The value presented in Table $2-0,661$, is owed to the fact that the respective item is in a reverse scale. In schools, at the beginning of the school year, the Class Director defines, according to his school hours, a day and a time to receive Guardians. These receiving hours usually coincide with the opening hours of the educational establishment. However, for most of the Guardians this schedule overlaps their office hours. To make this situation worse, many Guardians work outside their areas of residence, where educational establishments are usually located, which prevents them from attending the pre-scheduled meetings. Being a negative value, the inclusion of item 6 in factor 4 is carried out in a reverse scale.

In part $\mathrm{C}$ of the questionnaires ("Inclusion of items in an Electronic Report"), Teachers and Guardians were inquired about 7 items, as seen in Table 3.

The Kaiser Meyer Olkin (KMO) and Bartlett tests revealed a KMO value of 0.881 and a Bartlett significance value below $5 \%$, which allowed us to carry out the factor analysis, as the results were considered significant [2], [10].

After confirming the possibility of carrying out a factor analysis, and adopting the method of the principal components, we obtained our factors from the 7 variables, employing the Kaiser criterion (eigenvalues above one) and complying with the criterion that factors should explain at least approximately $60 \%$ of the total variation 
observed in the original variables [10]. We retained two factors, which explain $72.6 \%$ of the total variation observed in the 7 original variables [30].

Table 2. Rotation Method: Varimax with Kaiser normalization. Rotation converged in 5 iterations. $\mathrm{N}=1302$. $\mathrm{KMO}=0.887$.

\begin{tabular}{|c|c|c|c|c|}
\hline \multirow{2}{*}{ Items } & \multicolumn{4}{|l|}{ Factor } \\
\hline & 1 & 2 & 3 & 4 \\
\hline $\begin{array}{l}\text { 1. The relationship between the family } \\
\text { and the school is fundamental for the } \\
\text { teaching-learning process. }\end{array}$ & 0.050 & 0.702 & 0.017 & -0.057 \\
\hline $\begin{array}{l}\text { 2. The relationship between the school } \\
\text { and the family is not always easy and } \\
\text { stands out as a complex relationship. }\end{array}$ & 0.065 & 0.067 & 0.092 & 0.830 \\
\hline $\begin{array}{l}\text { 3. Whenever the parents are involved } \\
\text { the development of the students is } \\
\text { potentially improved. }\end{array}$ & 0.124 & 0.741 & 0.084 & 0.125 \\
\hline $\begin{array}{l}\text { 4. The participation of parents in the } \\
\text { school benefits the Teachers and } \\
\text { contributes to a more constructive work } \\
\text { on their part. }\end{array}$ & 0.166 & 0.724 & 0.104 & -0.023 \\
\hline $\begin{array}{l}\text { 5. Parents assume more favourable } \\
\text { attitudes towards Teachers when they } \\
\text { cooperate constructively with each other. }\end{array}$ & 0.101 & 0.749 & 0.117 & -0.052 \\
\hline $\begin{array}{l}\text { 6. Parents can easily head to the } \\
\text { school during the receiving hours } \\
\text { appointed by Class Directors and in } \\
\text { meeting days. }\end{array}$ & -0.095 & 0.155 & 0.295 & -0.661 \\
\hline $\begin{array}{l}\text { 7. The Traditional Student Record } \\
\text { constitutes an important tool in family- } \\
\text { school communications. }\end{array}$ & 0.024 & 0.220 & 0.808 & -0.074 \\
\hline $\begin{array}{l}\text { 8. Teachers regularly use the } \\
\text { Traditional Record in their } \\
\text { communications with Guardians. }\end{array}$ & 0.052 & 0.042 & 0.873 & -0.018 \\
\hline $\begin{array}{l}\text { 9. It is important to find a tool that } \\
\text { will allow for the intensification of and an } \\
\text { easier communication between the School } \\
\text { and the Guardian. }\end{array}$ & 0.474 & 0.286 & 0.100 & 0.341 \\
\hline $\begin{array}{l}\text { 10. The adoption of an Electronic } \\
\text { Report may contribute to an improved } \\
\text { communication between the school and } \\
\text { the Guardian. }\end{array}$ & 0.886 & 0.086 & -0.019 & 0.109 \\
\hline $\begin{array}{l}\text { 11. An Electronic Record may } \\
\text { constitute an important work tool for } \\
\text { Class Directors, Teachers, Parents and } \\
\text { School Principals. }\end{array}$ & 0.899 & 0.137 & -0.011 & 0.074 \\
\hline $\begin{array}{l}\text { 12. An Electronic Report may } \\
\text { constitute a communication resource } \\
\text { between every Teacher and Guardians. }\end{array}$ & 0.904 & 0.118 & -0.021 & 0.074 \\
\hline $\begin{array}{l}\text { 13. An Electronic Report may be used } \\
\text { by School Principals to contact Teachers. }\end{array}$ & 0.698 & 0.146 & 0.147 & -0.014 \\
\hline $\begin{array}{l}\text { 14. An Electronic Report may be used } \\
\text { by School Principals to contact } \\
\text { Guardians. }\end{array}$ & 0.896 & 0.080 & 0.045 & 0.017 \\
\hline $\begin{array}{l}\text { 15. An Electronic Record offers more } \\
\text { advantages than the Traditional Record } \\
\text { where the communication between the } \\
\text { multiple school community actors is } \\
\text { concerned. }\end{array}$ & 0.880 & 0.038 & -0.033 & 0.052 \\
\hline
\end{tabular}




\begin{tabular}{|l|l|l|r|r|}
\hline \% Explained variance & 31.8 & 15.7 & 10.5 & 8.6 \\
Total explained variance & 66.7 & & & \\
\hline
\end{tabular}

Table 3. Part $\mathrm{C}$ of the Teachers and Guardians questionnaires - "Inclusion of Items in an Electronic Report"

\begin{tabular}{|l|l|}
\hline $\begin{array}{l}\text { Part C of the Teachers and Guardians Questionnaires - "Inclusion of items in an } \\
\text { Electronic Report" }\end{array}$ \\
\hline Number & Item \\
\hline 1 & Absence justifications by the Guardians. \\
\hline 2 & Absence management by the Class Director. \\
\hline 3 & Mid-term evaluation record. \\
\hline 4 & Evaluation criteria and tools for each subject. \\
\hline 5 & Student self-assessment forms. \\
\hline 6 & $\begin{array}{l}\text { Communication management (Messages, SMS and Emails) between Class } \\
\text { Directors, Teachers and Guardians. }\end{array}$ \\
\hline 7 & Videoconference between Class Directors and Guardians. \\
\hline
\end{tabular}

Through the Varimax method we were able to obtain the extreme value of the coefficients relating each variable to the retained factors, connecting each variable to a single factor [5]: Factor 1 - evaluation and absence records, Factor 2 - student self-assessment and communication.

Table 4 shows the factorial matrix after the Varimax rotation, where the saturations between each factor as well as the principal components can be observed. The saturation of the variables in each factor stand above the required minimum of $40 \%$.

Table 4. Rotation Method - Varimax with Kaiser normalization. Rotation converged in 5 iterations. $\mathrm{N}=1302$. $\mathrm{KMO}=0,887$.

\begin{tabular}{|c|c|c|}
\hline \multirow{2}{*}{ Items } & \multicolumn{2}{|l|}{ Factor } \\
\hline & $\mathbf{1}$ & 2 \\
\hline 1. Absence justifications by the Guardians. & 0.861 & 0.141 \\
\hline 2. Absence management by the Class Director. & 0.868 & 0.248 \\
\hline 3. Mid-term evaluation record. & 0.767 & 0.405 \\
\hline 4. Evaluation criteria and tools for each subject. & 0.588 & 0.571 \\
\hline 5. Student self-assessment forms. & 0.439 & 0.667 \\
\hline $\begin{array}{l}\text { 6. Communication management (Messages, SMS and Emails) } \\
\text { between Class Directors, Teachers and Guardians. }\end{array}$ & 0.458 & 0.668 \\
\hline 7. Videoconference between Class Directors and Guardians. & 0.054 & $\mathbf{0 . 8 8 4}$ \\
\hline \% Explained variance & 40.5 & 32.1 \\
\hline Total explained variance & 72.6 & \\
\hline
\end{tabular}

In Part C of the questionnaires - "Inclusion of Items in an Electronic Report", the inclusion of two factors was substantiated. However, several items converged in more than one, and this justifies a subsequent analysis of the items individually (Table 4). 


\subsection{Internal Consistency Analysis of the Adopted Scales}

An internal consistency analysis, which allows us to study the properties of the measure scales and the questions they comprise, was carried out in Part B of the questionnaires.

The adopted scale was an ordinal Likert type scale, with five answer alternatives (from "1" to "5") ranging from "Completely disagree" to "Completely agree". It included 15 items, organized into 4 factors (Table 5).

Table 5. Organization of factors and respective items.

\begin{tabular}{|c|c|}
\hline Factors & Items \\
\hline $\begin{aligned} & \text { Factor } 1 \\
&- \text { ER }\end{aligned}$ & $\begin{array}{l}\text { 9. It is important to find a tool that will allow for the intensification of and } \\
\text { an easier communication between the School and the Guardian. } \\
\text { 10. The adoption of an Electronic Report may contribute to an improved } \\
\text { communication between the school and the Guardian. } \\
\text { 11. An Electronic Record may constitute an important work tool for Class } \\
\text { Directors, Teachers, Parents and School Principals. } \\
\text { 12. An Electronic Report may constitute a communication resource between } \\
\text { every Teacher and Guardians. } \\
\text { 13. An Electronic Report may be used by School Principals to contact } \\
\text { Teachers. } \\
\text { 14. An Electronic Report may be used by School Principals to contact } \\
\text { Guardians. } \\
\text { 15. An Electronic Record offers more advantages than the Traditional } \\
\text { Record where the communication between the multiple school community } \\
\text { actors is concerned. }\end{array}$ \\
\hline $\begin{array}{l}\text { Factor } 2 \\
\text { - Impact of } \\
\text { the school- } \\
\text { family } \\
\text { relationship } \\
\text { in the } \\
\text { teaching- } \\
\text { learning } \\
\text { process }\end{array}$ & $\begin{array}{l}\text { 1. The relationship between the family and the school is fundamental for the } \\
\text { teaching-learning process. } \\
\text { 3. Whenever the parents are involved the development of the students is } \\
\text { potentially improved. } \\
\text { 4. The participation of parents in the school benefits the Teachers and } \\
\text { contributes to a more constructive work on their part. } \\
\text { 5. Parents assume more favourable attitudes towards Teachers when they } \\
\text { cooperate constructively with each other. }\end{array}$ \\
\hline $\begin{aligned} & \text { Factor } 3 \\
&-\mathrm{TR}\end{aligned}$ & $\begin{array}{l}\text { 7. The Traditional Student Record constitutes an important tool in family- } \\
\text { school communications. } \\
\text { 8. Teachers regularly use the Traditional Record in their communications } \\
\text { with Guardians. }\end{array}$ \\
\hline $\begin{array}{l}\text { Factor } 4 \\
\text { - School- } \\
\text { family } \\
\text { relationship } \\
\text { difficulties }\end{array}$ & $\begin{array}{l}\text { 2. The relationship between the school and the family is not always easy and } \\
\text { stands out as a complex relationship. } \\
\text { ** 6. Parents can easily head to the school during the receiving hours } \\
\text { appointed by Class Directors and in meeting days. }\end{array}$ \\
\hline
\end{tabular}

In the first dimension, Factor 1 - ER, Cronbach's Alpha value is over 0.80, and the unidimensional data can be considered adequate (Table 6).

In Factor 2 - Impact of the school-family relationship in the teacher-learning process, Cronbach's Alpha is over 0.70, and the unidimensional data can be considered acceptable (Table 6). In Factor 3 - TR, Cronbach's Alpha value comes 
close to 0.70 , and the unidimensional data can be considered acceptable (Table 6). Finally, in Factor 4 - School-family relationship difficulties, Cronbach's Alpha is below 0.70, and the unidimensional data cannot be considered acceptable (Table 6).

The scale used in Part B - "Student Report", is suitable to measure the factors that were constructed for this sample, with the exception of factor 4; despite this limitation the scale was nevertheless used.

Additionally, we asked the Teachers and Guardians to indicate the advantages and disadvantages of using an ER. Suggested advantages by Teachers and Guardians concerning the use of an ER amounted to $84.7 \%$ and $84.3 \%$, respectively. As to disadvantages, we registered $24.3 \%$ for Teachers and $20.2 \%$ for Guardians. The most frequently referred advantages in the adoption of an ER, by Teachers and Guardians, were: "Faster, more efficient and safer communication"; "Saves paper"; "Decreases repetitive tasks"; "Customized access to information, at any given time and place"; "Daily follow-up" and "Virtual Presence". In their answers given to the question involving the disadvantages of adopting an ER the respondents were objective, indicating the inexistence of disadvantages, the possible lack of internet access by some and, mainly, the lack of computer skills.

Table 6. Cronbach's Alpha results for each factor

\begin{tabular}{|c|c|c|c|}
\hline Factor 1 & & Factor 2 & \\
\hline Cronbach's Alpha & Nr. of Items & Cronbach's Alpha & Nr. of Items \\
\hline 0.922 & 7 & 0.730 & 4 \\
\hline Factor 3 & & Factor 3 & \\
\hline Cronbach's Alpha & Nr. of Items & Cronbach's Alpha & Nr. of Items \\
\hline 0.661 & 4 & 0.661 & 4 \\
\hline
\end{tabular}

Part $\mathrm{C}$ of the Guardians and Teachers questionnaire focused on the inclusion of items in an ER. We observed that $95 \%$ of the Guardians and $94 \%$ of the teachers believe that all the items of the TR should be included in an ER.

We asked the Guardians and the teachers to indicate their level of agreement as to the inclusion of the following items in a prospective ER, as shown in Table 7.

Table 7. Inclusion of items in a prospective ER

\begin{tabular}{|rl|}
\hline \multicolumn{1}{|c|}{ Items } \\
\hline 1. & Absence justifications by the Guardians. \\
\hline 2. & Absence management by the Class Director. \\
\hline 3. & Mid-term evaluation record. \\
\hline 4. & Evaluation criteria and tools for each subject. \\
\hline 6. & Student self-assessment forms. \\
\hline 7. & Communication management (Messages, SMS and Emails) \\
\hline
\end{tabular}


From the obtained answers, all items reveal a high average agreement, higher for statements 3,1 and 2 followed by 4, 6, 5 and 7 .

From the answers given by the Teachers in our study sample, the items that reveal a higher average agreement involve the statements 2, 3, 4, 6 and 1 followed by 5, and lower for 7 . We also asked our study participants to identify some of the items that, in their view, should be included in an ER. Faced with multiple responses, we opted for the inclusion of the most significant, namely the record of absences, mid-term evaluations, record of school entries and exits and communication between Guardians.most welcome.

\section{Presentation and Discussion of the results concerning the Investigation Questions}

The developed study was based on a set of questions included both in the questionnaire given to Guardians and in the questionnaire given to Teachers, which were subject to analysis.

The first investigation questions, "School-family communication is fundamental for the teaching-learning process", relates to Factor 2 - Impact of the school-family relationship in the teaching-learning process, and comprises the following statements: $1,3,4$ and 5 (Table 5).

The majority of Guardians (96.7\%) believes that the relationship between the school and the family is fundamental for the teaching-learning process. This is also the perception expressed by the majority of Teachers (99.3\%).

The observed average values reveal the presented variations, with all items showing a high level of agreement, both for Guardians and Teachers. Factor 2 Impact of the school-family relationship in the teaching-learning process, thus reveals an average value of 4.49 for Guardians and of 4.55 for Teachers, which come significantly close to the maximum possible value. In conclusion, we can say that both for Guardians and Teachers, the communication between the school and the family is fundamental for the teaching-learning process.

The analysis of the second investigation question "The TR is a fundamental tool in school-family communication" relates to Factor 3 - TR, and comprises statements: 7 and 8 (Table 5). Teachers regularly use the student TR when communicating with Guardians. Indeed, both Guardians $(88,8 \%)$ and Teachers $(87,9 \%)$ perceive the student TR as an important school-family communication tool.

The observed average values reveal the presented variations, with all items showing a high level of agreement, both for Guardians and Teachers. Factor 3 - TR, thus reveals an average value of 4.20 for Guardians and of 4.13 for Teachers, which come significantly close to the maximum possible value. In conclusion, we can say that both for Guardians and Teachers, the TR constitutes a fundamental school-family communication tool.

The analysis of the investigation question "The ER improves school-family communication", relates to the analysis of Factor $1-\mathrm{ER}$, and comprises statements: $9,10,11,12,13,14$ and 15 (Table 5). 
In our sample, Guardians (83.9\%) and Teachers (92.3\%) are unanimous as to the relevancy of finding a tool that allows for the intensification of and an easier communication between the school and the Guardian. Guardians (78\%) and Teachers $(87.3 \%)$ go so far as to admit that an ER may become a communication and work resource, between the school and the family. The majority of Guardians (73\%) and Teachers $(82 \%)$ believe that the ER may bring more benefits when compared with the TR.

The observed average values reveal the presented variations, with all items showing a high level of agreement, both of Guardians and Teachers. Factor 1 - ER, thus reveals an average value of 4.11 for Guardians and of 4.33 for Teachers, which come significantly close to the maximum possible value.

In conclusion, we can say that both Guardians and Teachers believe that the ER promotes and improves the communication between the school and the family.

The herein presented measures of dispersion reveal relatively low values for the standard deviation, with values below one or coefficient of variation percentages of twenty or less (Tables 8, 9 and 10). Therefore, everything suggests a good dispersion of the obtained results, pointing to a greater homogenization of answers and, consequently, an average value that is more representative of reality.

Table 8. Measures of Dispersion of Factor 2 - Influence of the School/Family relationship in the teaching-learning process and its items.

\begin{tabular}{|c|c|c|c|c|c|c|c|c|}
\hline & Gual & dians & & & Teac & hers & & \\
\hline & $\mathrm{N}$ & Average & $\begin{array}{l}\text { Standard } \\
\text { Deviation }\end{array}$ & \begin{tabular}{|c} 
Coefficient \\
of \\
Variation
\end{tabular} & $\mathrm{N}$ & Average & $\begin{array}{l}\text { Standard } \\
\text { Deviation }\end{array}$ & $\begin{array}{c}\text { Coefficient } \\
\text { of } \\
\text { Variation }\end{array}$ \\
\hline $\begin{array}{l}\text { Factor } 2 \text { - Influence of the } \\
\text { school-family relationship } \\
\text { in the teaching-learning } \\
\text { process. }\end{array}$ & $\begin{array}{l}10 \\
02\end{array}$ & 4,49 & 0,54 & $12 \%$ & $\begin{array}{r}30 \\
0 \\
\end{array}$ & 4,55 & 0,47 & $10 \%$ \\
\hline $\begin{array}{l}\text { 1. The relationship between } \\
\text { the school and the family is } \\
\text { fundamental for the } \\
\text { teaching-learning process. }\end{array}$ & $\begin{array}{l}10 \\
02\end{array}$ & 4,79 & 0,53 & $11 \%$ & $\begin{array}{r}30 \\
0 \\
\end{array}$ & 4,82 & 0,44 & $9 \%$ \\
\hline $\begin{array}{l}\text { 3. Whenever the parents } \\
\text { are involved, the } \\
\text { development conditions of } \\
\text { the students are potentially } \\
\text { improved. }\end{array}$ & $\begin{array}{l}10 \\
01\end{array}$ & 4,37 & 0,79 & $18 \%$ & $\begin{array}{r}29 \\
9\end{array}$ & 4,47 & 0,74 & $17 \%$ \\
\hline $\begin{array}{l}\text { 4. The participation of the } \\
\text { parents in the school } \\
\text { benefits the Teachers, and } \\
\text { contributes to a more } \\
\text { constructive work on their } \\
\text { part. }\end{array}$ & $\begin{array}{l}10 \\
01 \\
\end{array}$ & 4,34 & 0,79 & $18 \%$ & $\begin{array}{r}29 \\
9 \\
\end{array}$ & 4,31 & 0,77 & $18 \%$ \\
\hline $\begin{array}{l}\text { 5. Parents assume more } \\
\text { favourable attitudes towards } \\
\text { Teachers when they } \\
\text { cooperate constructively } \\
\text { with each other. }\end{array}$ & $\begin{array}{l}10 \\
01\end{array}$ & 4,47 & 0,74 & $16 \%$ & $\begin{array}{r}29 \\
9\end{array}$ & 4,60 & 0,61 & $13 \%$ \\
\hline
\end{tabular}


Table 9. Measures of Dispersion of Factor 3-TR.

\begin{tabular}{|c|c|c|c|c|c|c|c|c|}
\hline & \multicolumn{4}{|c|}{ Guardian } & \multicolumn{4}{|c|}{ Teacher } \\
\hline & $\mathrm{N}$ & Average & $\begin{array}{l}\text { Standard } \\
\text { Deviation }\end{array}$ & $\begin{array}{l}\text { Coefficient } \\
\text { of } \\
\text { Variation }\end{array}$ & $\mathrm{N}$ & Average & $\begin{array}{l}\text { Standard } \\
\text { Deviation }\end{array}$ & $\begin{array}{c}\begin{array}{c}\text { Coefficient } \\
\text { of } \\
\text { Variation }\end{array} \\
\end{array}$ \\
\hline Factor 3 - Traditional Record & $\begin{array}{l}10 \\
02 \\
\end{array}$ & 4,20 & 0,83 & $20 \%$ & $\begin{array}{r}30 \\
0 \\
\end{array}$ & 4,13 & 0,73 & $18 \%$ \\
\hline $\begin{array}{l}\text { 7. The Traditional Student } \\
\text { Record constitutes an } \\
\text { important tool in family-school } \\
\text { communications. }\end{array}$ & $\begin{array}{l}10 \\
02\end{array}$ & 4,49 & 0,82 & $18 \%$ & $\begin{array}{r}29 \\
9\end{array}$ & 4,33 & 0,79 & $18 \%$ \\
\hline $\begin{array}{l}\text { 8. Teachers regularly use the } \\
\text { Traditional Record in their } \\
\text { communications } \\
\text { Guardians. }\end{array}$ & $\begin{array}{l}10 \\
02\end{array}$ & 3,91 & 1,08 & $28 \%$ & $\begin{array}{r}30 \\
0\end{array}$ & 3,94 & 0,91 & $23 \%$ \\
\hline
\end{tabular}

Table 10. Measures of Dispersion of Factor 1 - ER.

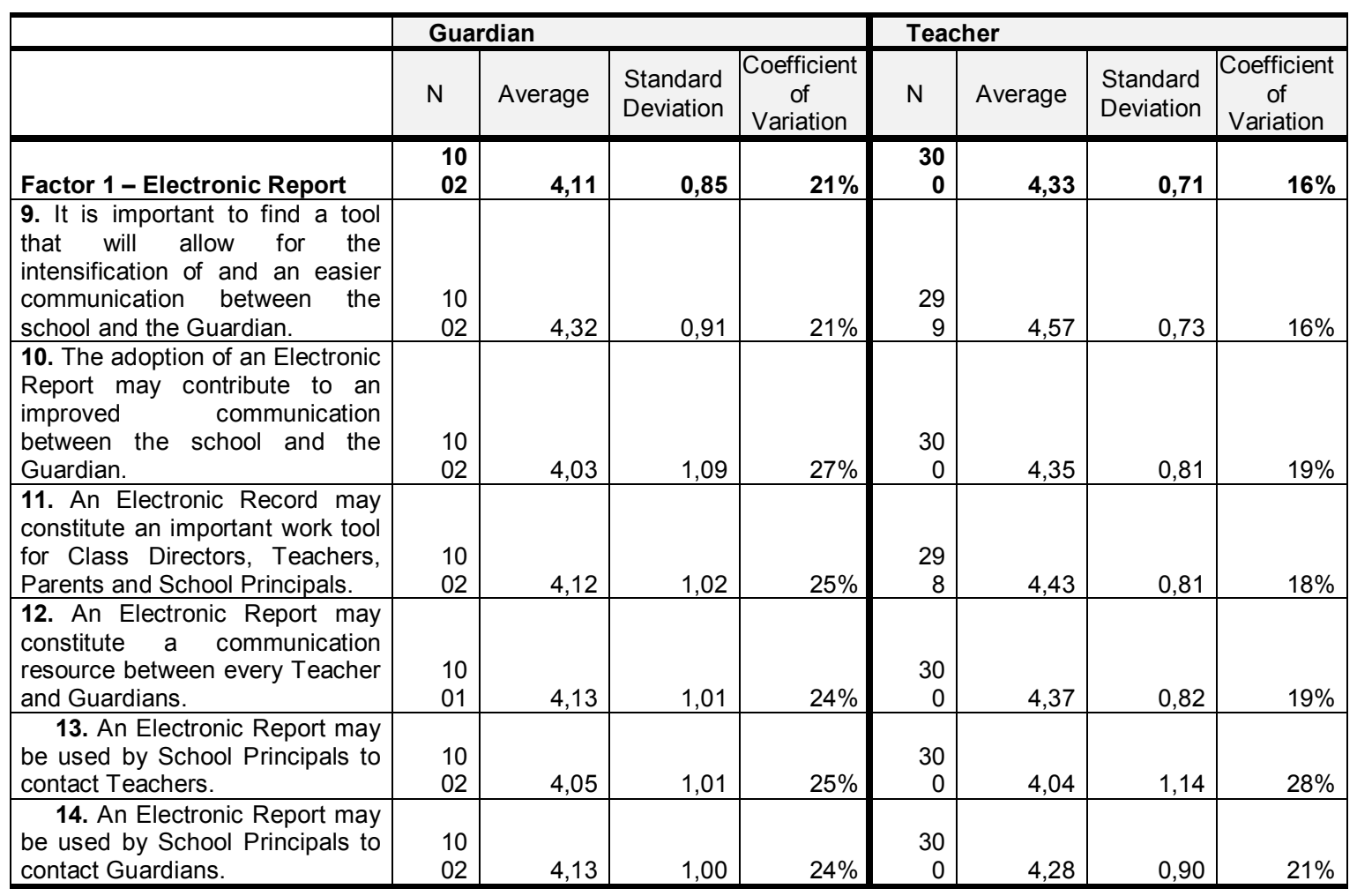




\section{Conclusion}

The collaboration between the school and the family, two fundamental institutions for the education of the child, is essential to improve the teaching-learning process, and promotes the desired educational success. Education is a task that must be shared by Teachers, Guardians and community institutions [22]. Because we believe that, in the teaching-learning process as a whole, communication and, particularly, the means with which we communicate, are essential to educational success, we directed our study to understand the opinion of Guardians and Teachers as to the feasibility of adopting an ER in the school-family relationship.

As a starting point for the development of this study we posed three hypothesis: H1: The educational community values communication between the school and the family; H2: The TR is a fundamental tool in school-family communication; H3: The ER improves school-family communication.

We concluded, based on the collected answers, that Teachers and Guardians perceive school-family communication as being fundamental in the teaching-learning process, to the extent that the factor concerning the impact of the school-family relationship in the teaching-learning process obtained an average of 4.49 amongst Guardians and 4.55 amongst Teachers, which comes significantly close to the maximum value possible. For Teachers and Guardians, the TR constitutes a fundamental tool in school-family communications. Currently, the TR is, for Guardians, the only vehicle of communication with Teachers, as they cannot head to school during opening hours. From the point of view of the Guardians and Teachers who participated in the study, the ER can promote and improve school-family communications. Indeed, the analysis carried out to the answers collected from our study participants led us to conclude that the Factor $1-$ ER, reveals an average value of 4.11 amongst Guardians and of 4.33 amongst Teachers, which come significantly close to the maximum value possible. The majority of Teachers and Guardians asserts that the ER should include the items that are already available in the TR. They also stress the importance of including the following items: record of absences, mid-term evaluations, record of entries and exits from school, as well as communication amongst Guardians.

Considering the obtained results, we observed that the three hypothesis were reinforced, as the majority of the respondents (Guardians and Teachers), believe that the communication between the school and the family is fundamental for the teaching-learning process; moreover, the TR emerges as fundamental tool in schoolfamily communications and the ER promotes and improves this school-family communication.

Therefore, the ER may assume, in a ground breaking, dynamic and assertive way, a facilitating role in school-family communications, allowing for the development of partnerships.

In this sense, the development of a web application, the ER, is justified, to enable the consultation of the entire body of information concerning the student and promote an easier, quicker and safer communication between the school and the family. 


\section{References}

1. Abrantes, B. (2009). Conceção e Desenvolvimento de um Ambiente de Aprendizagem Pessoal Baseado em Ferramentas Web 2.0. Universidade de Aveiro.

2. Bartlett, M. S. (1951). The effect of standardization on a chi square approximation in fator analysis. Biometrika. 337-344.

3. Berto, R. M. V. S. and N. D. N. (2000). A Produção Científica nos Anais do Encontro Nacional de Engenharia de Produção: Um Levantamento de Métodos e Tipos de Pesquisa. Revista Produção, 9 (2), 65-76.

4. Boonen, A. (2000). Pourquoi utiliser les technologies de l'information et de la communicationdans le domaine de l'éducation? In J. J. Scheffknecht (Ed.), Les technologies de l'informationà l'école: raisons et stratégies pour un investissement. Strasbourg: Conseil de l'Europe.

5. Costello, A. \& J. Osborne (2005). Best Practices in Exploratory Fator Analysis: Four Recommendations for Getting the Most from your Analysis. Pratical Assessment, Research \& Evaluation, 1-9.

6. Groves, R. M., Brick, M. J., Couper, M., Kalsbeek, W., Harris-Kojetin, B., Kreuter, F., . . Tourangeau, R. (2004). Survey Methodology. Wiley: Hoboken, NJ.

7. Guimarães, R. C. \& J. A. Sarsfield Cabral (2010). Estatística, $2^{\mathrm{a}}$ Edição. Verlag Dashöfer.

8. Hair, J. F., Anderson, R. E., Tatham, R. L., \& Black, W. C. (2005). Análise multivariada de dados. 5.ed. . Porto Alegre: Bookman.

9. Jiménez, E. G., J. Flores, et al. (2000). Cuadernos de estadística: análisis factorial. Salamanca: La Muralla, 2000.

10. Kaiser, H. F. (1974). An index of fatorial simplicity. Psychometrika, 31-36.

11. Lee, H. \& Whitley, E. A. (2002). Time and Information Technology: Temporal Impacts on Individuals, Organizations, and Society. The Information Society, 18, 235-240.

12. Leong, F. T. L. and J. T. Austin (2006). The Psychology Research Handbook. Second Edition. Sage Publications, Thousand Oaks, California, 516.

13. Lévy, P. (2003). Cibercultura. São Paulo, (34).

14. Lima, L., \& Sá, V. (2002). A participação dos pais na governação democrática das escolas. In: Lima, J. (Org.). Pais e professores, um desafio à cooperação. Porto: Edições Asa.

15. Lourenço, L. P. R. (2008). Envolvimento dos Encarregados de Educação na Escola: Conceções e Práticas. Universidade de Lisboa.

16. Marques, R. (1992). Colaboração Escola-Famílias: um conceito para melhorar a Educação. Ler Educação, 8.

17. Marques, R. (1993). A escola e os pais: como colaborar? . Lisboa: Texto Editora.

18. Marques, R. (1998). Os desafios da sociedade de informação. In R. Marques, M.

19. Mattelart, A. (2003). The Information Society. London: Sage Publications.

20. McLean, N. (2009). Technology can bridge the gap between parents and schools. The Independent.

21. Montadon, C., \& Perrenoud, P. (2001). Entre pais e professores, um diálogo impossível? Para uma análise sociológica das interações entre a família e a escola. Oeiras: Celta

22. Paro, V. (2003). Qualidade do Ensino: A Contribuição dos Pais. São Paulo: Xamã.

23. Pereira, A. (2006). Análise de dados para Ciências Sociais e Psicologia. Lisboa: Edições Sílabo.

24. Pereira, C. B. (2004). O marketing do lugarzinho: uma aplicação exploratória da técnica de índice de preços hedônicos a jovens consumidores de restaurantes na cidade de São Paulo. Tese de Doutoramento em Administração - Faculdade de Economia, Administração e Contabilidade, Universidade de São Paulo. São Paulo, 165. 
25. Salvador, P.; Rocha, Á.. 2014. An Assessment of Content Quality in Websites of Basic and Secondary Portuguese Schools, In Rocha et al. (Eds.) New Perspectives in Information Systems and Technologies, Volume I, Advances in Intelligente Systems and Computing 275. Springer International Publishing Switzerland.

26. Sarmento, T. (2005). (RE)pensar a interação escola família. Revista Portuguesa de Educação, 18 (53-75).

27. Sarmento, T., \& Marques, J. (2002). A Escola e os Pais, Coleção Infans. Braga: Centro de Estudos da Criança.

28. Silva, P. (2002). Escola-família: Tensões e potencialidades de uma relação. in Jorge Ávila de Lima (Org.), Pais e Professores, Um Desafio à Cooperação. Porto, Edições ASA.

29. Stevens, J. (1996). Applied multivariate statistics for the social sciences (3rd edn). Mahway, NJ: Lawrence Erlbaum.

30. Tabachnik, B. G., \& Fidell, L. S. (2006). Using Multivariate Statistics. (5.th Ed.). Pearson Education.

31. Unctad (2011). Measuring the Impacts of Information and Communication Technology for Development, UNCTAD Current Studies on Science, Technology and Innovation, (3).

32. Villas-Boas, M. (2000). A parceria entre a escola, a família e a comunidade: reuniões de pais. Lisboa: Edição do Departamento de Avaliação Prospetiva e Planeamento do Ministério da Educação.

33. Villas-Boas, M. (2001). Escola e família: uma relação produtiva de aprendizagem em sociedades multiculturais. Lisboa: Escola Superior João de Deus. 